\title{
MODERNIZATION AND THE REPRODUCTION OF EVERYDAY LIFE IN KONYA
}

\author{
Necdet Subaş 1 \\ The Presidency of Religious Affairs, Ankara-Turkey
}

\begin{abstract}
In this paper, modernity and the practices of everyday life are evaluated, selecting Konya as a case study. Everyday life reflects the norm of values, approaches, and actions that are brought into being in society in various ways. Konya constitutes a unique example for those who want to observe the continuity of Turkish modernism, because it is a city where modernity and desires for a traditional life meet in a paradoxical manner; it is a unique city in that it enables hybrid encounters of the modern and traditional to occur in everyday life practices. This study is an effort to understand how the attributes of the modern and the traditional shape everyday life, as well as to provide a discussion of its current problems.
\end{abstract}

Key Words: Everyday life, modernity, religiosity, tradition, traditionalism, Turkish culture, Konya, urban culture, cultural heritage

Yahya Kemal (1884-1958), one of the leading figures of contemporary Turkish literature, could not help asking a paradoxical question while critically examining the social structures transformed in haste by modernity: "Is it possible to wake up for the early morning prayer (șalāt al-fajr) after a night of infidel life?" Yahya Kemal personally

1 See Yahya Kemal Beyatl1, Aziz İstanbul [Glorious Istanbul] (Istanbul: İstanbul Fetih Cemiyeti, 1964). 
witnessed the interventions made in the early Republican Era by modernist practices towards the integrity of traditional life, and the excitement that was aimed at completely upsetting traditional ways of thinking, and he thus expressed his observations and his growing worries.

Yahya Kemal argues that șalat, or the prayers made by Muslims five times a day, is at the top of the list of principles that must be preserved and continued. In fact, when common religious references among Muslims are used as a starting point, it is undeniable that șalāt is regarded as the central pillar of the faith. For example, within the predominant Islamic tradition, the Islamic faith of a group who does not practice șalāt is often questioned. Yahya Kemal's aforementioned question is not referring to simply any prayer, but the early morning prayer. What makes the question more relevant is the fact that the early morning prayer is especially difficult to practice. ${ }^{2}$ This difficulty increases with the increasingly modern way of life.

It is possible for Yahya Kemal's question to be discussed on several levels. What Yahya Kemal meant by "foreign" (Frenk) life was that the world was now being conceptualized as if it were the West. Traditional ways of life now had to adapt in an increasingly radical manner to the values of the Western (Frenk) world. The dynamism inherent in the westernization process was rendering what is traditional as disputable, eroding and obliterating the value and status of all that belonged to the past. For a typically "modern" man, this approach made compromising the most fundamental components of the traditional the only goal. ${ }^{3}$ Thus, the boundaries between the Western way of thinking and the long-established world of the traditional were

2 The early morning prayer, șalāt al-fajr, is considered to be an important dividing line to distinguish the true believer ( $m u^{\prime}$ 'min) from the impostor (munäfiq) and thus gains a special status owing to its difficulty. Şalāt al-fajr in question is performed in the early hours of the day before the sun rises. The flow of daily routines in the traditional way of living was designed taking into consideration the time of the five daily prayers. To perform the daily prayers comfortably, the activities of daily life had to be planned according to them. Therefore, one who wishes to perform the early morning prayer is expected to go to bed early. However, the only way for a Muslim to perform daily prayers in a modern and secular way of life is to search for suitable breaks for each one.

3 Howard Alexander Reed, "Çağdaş Türk Müslümanlarının Dinî Hayatı [Religious Life of Modern Turkish Muslims]" in Davut Dursun (ed.), Türkiye'de İslâm ve Laiklik [Islam and Laicism in Turkey] (Istanbul: İnsan Yayınları, 1995), 91-127. 
now being codified as a constant source of tension for the Republican generations. Everyday life had to change.

The question Yahya Kemal asked in fact reflects the paradoxes created by the oscillations and dilemmas between modern and traditional views of life. This question points to an impasse experienced not only by Turks but also by all the "other" societies involved in the modernization process: how could it be possible to wake up for the early morning prayer, or șalät al-fajr, which is one of the most sensitive presentations of the religious obligations, in a universe where daily life is built on the foundation of laic practices and secular demands? What is left of the differentiation of time and space in everyday life? When these differentiations are pondered, the basic question that crystallizes appears to be an impasse that summarizes the de facto realities of Muslim communities that have existed for approximately 200 years. The problem revolves around the question, "Could we be both Western and Muslim?"

Modernization ${ }^{5}$ brought critical challenges that arose at certain points in Turkey as a result of the reproduction of everyday life, as also occurred in many other traditional communities. The desire for secularization, which is inherent in the founding discourse of modernism, reveals the flexibility of the boundaries of Islamic mod-

4 İsmail Kara, "İslâm Düşüncesinde Paradigma Değişimi: Hem Batılılaşalım Hem de Müslüman Kalalım [Paradigm Shift in Islamic Thought: Let's Both Become Westernalized and Remain Muslims]" in Mehmet Ö. Alkan (ed.), Modern Türkiye'de Siyasi Düşünce: Tanzimat ve Meşrutiyet'in Birikimi [Political Thought in Modern Turkey: Accumulation of Tanzīmāt and Constitutionalism] (Istanbul: İletişim Yayınları, 2001), I, 234-264.

5 Usually, under the title of modernization, three often confused developments are mentioned. The first is a process of confusion and transformation that encompasses the whole society, which is self-originating and self-growing process that arises as a result of fostering independent actions of actors belonging to different social groups. The second is a purposeful re-building process aimed at connecting this process of growth, expansion, and transformation with new behavioral and institutional norms. These two dimensions, which involve economic and social dynamics and the political and legal framework that try to guide them, are together called modernization. The third are efforts to express the gaps and weaknesses under this social structure, which in the narrowest sense of the word come to mean modernism. See İhsan Bilgin, "Modernleşmenin Şehirdeki İzleri [Marks of Modernisation in the City]," www.arkitera.com/v1/diyalog/ibsanbilgin/ modernizm1.htm (2002). 
ernization. The style of modernization in everyday life, particularly in cities with traditional leanings such as Konya and Kayseri (both of which do not resist so strongly, but incorporate their own preferences), reflects this flexibility. In this context, certain lifestyles that do not fear resorting to modernity or tradition can be considered serious exceptions to the usual debates and generalizing assumptions of sociologists. ${ }^{6}$

\section{On Everyday Life}

Daily life reflects the ordinary world of values, attitudes and activities that take shape in various forms in social life. Therefore, it would not be an exaggeration to consider studies of daily life among the most effective means that can be used to trace changes in social structure; thus, daily life patterns, living designs, mental structures, perceptions of the world, conceptions of life and the confusions and differentiations from the ordinary can be observed clearly. ${ }^{7}$

The significance of daily life arises from the fact that it is the simplest demonstration of reality. Although this topic is regarded as a fairly new area of study in the social sciences, it indicates the original course of social reality. In the same vein, sociological studies focus on

6 A study conducted by the European Stability Initiative (ESI) in 2005 defined the dynamic entrepreneurial spirit and the efforts to join in with the modern in Kayseri, an Anatolian city known for its conservatism, as a Calvinist development of its own kind. In that study, the activity in Kayseri was reflected as a perfect identification of Islam with modernity. According to the study, economic success and social development took the form of a harmony between Islam and modernity. Discussions of Protestantism generated by sociological analyses made to understand the relationship between religion and capitalism since Weber was brought to the agenda as a model that had explanatory power on this issue. It was obvious that when themes of change, progress, and differentiation in the Islamic world came to the agenda, the controversy would get deeper and go in different directions. The worldview of Islam requires new concepts because the means at hand are usually insufficient and useless. Thanks to undeniable examples of the fact that Islamic tradition did not fear from getting in touch with new realities, the new forms generated by these contacts increase and rapidly assume an Islamic character. Even so, this reciprocity may always be a source of surprise for Western researches.

7 In this context, the contributions of Erving Goffman, Harold Garfinkel, Alfred Schutz, Thomas Luckman, and Henri Lefebvre must be particularly remembered; see Necdet Subaş1, Gündelik Hayat ve Dinsellik [Daily Life and Religiosity] (Istanbul: İz Yayınc1l1k, 2004). 
how people operate in their daily lives. In this framework, ethnography has a particular explanatory power with high sociological value in daily life studies. Accordingly, daily life reflects an experience in which everyone becomes involved in some way. As noted by Henri Lefebvre, ${ }^{8}$

daily life in all its ordinariness is composed of repetitions: attitudes at work and outside work, mechanical movements (...), hours, days, weeks, months, years; linear and cyclical repetitions, natural time and rational time, etc. (...) Daily life is a low degree of 'experience' and thinking, a degree in which experience and thinking have not separated from one another yet; all that is perceived is a part of a larger universe, and the world is a total of all things.

Thus, daily life is a shared and dynamic world of experience from which objects and abstract concepts are generated.

Daily life is not independent of any discourse that determines itself, no matter which context it is in. Daily life, which is usually bound by ordinariness, is a specific form(ality) that requires a substantial hermeneutic effort, and what comes to surface are the hidden, deep, and strong undercurrents of the social. The system that regulates the flow of daily life is fed by a root paradigm involving the components of sociality and a reference system. This connection moves daily life to a status of a specific road map that renders it a constant determinant at a cognitive level. Thus, each form, action, or type of information that has an equivalent in life that is experienced and exposes itself, reflects the inner world of the social. By pursuing the traces of changes existing in daily life, it becomes possible to demystify and understand the social and economic assets of a world of differentiations and orientations that occur in a specific spatial and social context, or a world that has become ordinary through repetitions and habits. In this framework, daily life demonstrates how values, meanings, and actions that proliferate in a series ranging from the harmony in the relationships between the world and the religion, to the overlapping of the relationships between the state and society, can lead to unity in practice. There, some fanciful ideas, and odd and ambiguous preferences, or anything that has not turned into a daily form or style, carries an alienation that leaves itself outside. In this

See Henri Lefebvre, Modern Dünyada Gündelik Hayat [La Vie Quotidienne Dans le Monde Moderne] (translated into Turkish by Işın Gürbüz; Istanbul: Metis Yayınlar1, 1998). 
case, the essential goal is to discover the fundamental fragments of daily life that are interesting but always involved in social life by permeating through its effective filters. Furthermore, experimentalism and genuineness that are inherent in the nature of daily life always exist together with a grandiosity, style, and system. In short, when separated from daily life practices, the society's world of meaning, mental structures, living patterns, and objects of orientation are revealed. This study focuses on the reproduction of everyday life as a means of understanding the specific characteristics specifics that Konya has displayed through its process of modernization.

\section{Konya: "Encoded" and "Protected" Memory}

Konya can be regarded as an exceptional example in observing how modernization is faring in Turkey, because it is a model city where modernity and desires for tradition converge paradoxically like nowhere else. This existing reconciliation enables the emergence of new styles in daily life. With respect to the course of Turkish modernization, Konya is worthy of attention due to the interestingly simultaneous and unbiased references it makes to both tradition and modernity. Konya's historical memory as a city and its usual calmness in the face of all types of novelties distinguishes its form of modernization from others. First, being one of the few cities that have transcended the borders of Turkey, Konya sets an unequalled example in pursuing this course: on the one hand, Konya can be defined based on its classic and traditional urban identity; on the other hand, Konya demonstrates a desire on the part of the periphery to come to the center and activates a new potential for concentration. When the history of Konya is considered in terms of diversification of daily life, it is always possible to observe in it new strategies for existence. Accompanied by centrifugal tensions, Konya crystallizes the psychological state of the "provincial" in the process of Westernization and its story in this context.

In Konya, which is among the leading classic Anatolian cities, the past is updated anew without being limited only to the remembrance and conservation of the traditional. At the same time, efforts to create a new common ground for meeting with the modern are often observed in the historical process. Konya is one of the traditional Anatolian cities where all stages of its evolution from the traditional to the modern are experienced deeply and where the constantly controversial, tense and unsettling effects of change can never be ignored. However, the ultimate characteristic that separates Konya from simi- 
lar cities is that there still exists a piece of world knowledge or a guidebook of everyday life in it, which keeps a balanced distance between the traditional and the modern and even encourages this correlation between the two. Observing how everyday life goes on in the case of Konya appears to prove that demands for change can also be realized without leading to social confusion and "a fit of uneasiness" as is observed in the rest of Turkish modernity. Thus, it can be possible to understand that a typical Anatolian city can have a lifestyle that is open to both the traditional and the modern world without having to lead to a dilemma.

Even when a quick tour is taken through history, it is likely to confront the reality that Konya bears the characteristics of an ancient city. A common point that emerges from all archaeological findings since Neolithic times is that Konya has enjoyed a central status since the very beginning. ${ }^{10}$ This status can be explained with reference to its possession of a historically favorable location throughout the ages. Therefore, Konya's geography, which has continuously been overturned in power since the Hittite times, bears qualities that are worth investigating for their own sake.

Konya has enjoyed a strategic location since the time of the Romans, Byzantines, Muslim Arabs, and the Seljuqs. Additionally, the

9 Gregory Jusdanis, in a study in which he dealt with the fate of a modernization project in a society unprepared for it, he uses the concept of "belated modernity" and makes remarks about a "fit of uneasiness" experienced by communities in which there is a discordance between projects of modernization and local conditions. In his assessment of tensions between the center and the periphery, and the dominant and the minority, Jusdanis states that this "fit of uneasiness" actually stems from the differences between the West and the local conditions of the countries in the periphery. See Gregory Jusdanis, Gecikmis Modernlik ve Estetik Kültür [Belated Modernity and Aesthetic Culture] (translated into Turkish by Tuncay Birkan; Istanbul: Metis Yayınlar1, 1998).

10 In this framework, Çatalhöyük, one of the oldest human settlements in Anatolia and actually in the whole world is situated quite close to today's Konya (For Çatalhöyük, please see Hasan Bahar, Güngör Karauğuz, and Özdemir Koçak, Eskiçağ Konya Araştırmaları I: Phrygia Paroreus Bölgesi Anttlar, Yerleşmeler ve Küçük Buluntular [Studies on Konya in Ancient Times I: The Region of Phrygia Paroreus Monuments, Settlements, and Small Findings] (Istanbul: n.p., 1996); Hasan Bahar and Özdemir Koçak, Eskiçă̆ Konya Araştırmalar II: Neolitik Çağ'dan Roma Dönemi Sonuna Kadar [Studies on Konya in Ancient Times II: From the Neolithic Age to the End of the Roman Period] (Konya: Kömen Yayınlar1, 2004). 
Romans and Crusaders competed in their campaigns from the West to the East with the Mongols, in their incursions from the East to the West, inflicting similar destructions in the course of history. During the time of the Seljuqs, however, Konya began to be defined as a Turkish city, but they managed to keep Konya, together with its other peripheral cultural qualities that it had acquired through history, in a condition worthy of attention. For example, Konya always enjoyed a critical location for the Romans. Likewise, this characteristic was always of interest for the Byzantines. Konya's cosmopolitan nature and its location as an important station on the way of migrations and the Silk Road were among the elements that reinforced Konya's significance.

However, today, Konya derives its much-appreciated merit from a past that is primarily shaped by a spiritual tradition. Konya's past, which can always be associated with a kind of sanctity, provides it with a privilege that cannot be ignored. Konya's hidden history, or the image this city holds for a typical Konya resident, also exposes an emphasis on the roots of the city associated with a mythical world. It is necessary to note that the sanctity of this city exists in the minds of people from which a series of myths connects it with its pre-Islamic name, Iconium, to its name in the Islamic era, Konya. In this framework, Konya is referred to as "the city of prophets" or "the city of saints." Although oftentimes all of these names reflect states where myths and reality intermingle, a rather significant image derives its power from such references. For example, when one glances at the map of holy places in the New Testament, Konya becomes significant for the Christian tradition. This significance primarily derives from the fact that Saint Paul visited this city twice. Another point that must not be ignored regarding the emergence of the city image of Konya is the special significance attached to this city by the Christians during their holy wars, namely, the Crusades.

Undoubtedly, Konya has been a Turkish city for quite a long time. Conquered by the Seljuq commander, Sulaymān ibn Qutalmish, Konya has been in the hands of Muslim Turks since its conquest in 1074. It must not be forgotten that the real image of Konya, which has been

11 Cf. İbrahim Hakk1 Konyalı, Abideleri ve Kitabeleriyle Konya Taribi [History of Konya with Memorials and Epitaphs] (Konya: Yeni Kitap Basımevi, 1964); Hasan Özönder, Konya Velileri [Saints of Konya] (Konya: Kuzucular Ofset, 1990); Mehmet Ali Uz, Konya Alimleri ve Evliyalar [Scholars and Saints of Konya] (Konya: Karabulut, 1993). 
shaped by various efforts of the Seljuqs, Ottomans and modern Turks, can be revealed by associating it primarily with its Seljuq history. ${ }^{12}$ Konya served as the capital city during the reign of Anatolian Seljuqs. Although Konya appears to be a city that has continuously changed hands among Muslim communities from that time onward, this phenomenon primarily resulted from its status as a charismatic city. ${ }^{13}$

Indeed, the real quality of Konya that earned it worldwide fame is its association with the famous Islamic mystic Mawlānā Jalāl al-Dīn alRūmī. Al-Rūmī is not a mystic whose influence is known and felt only in Konya. In fact, many people who pay respectful attention to his message travel to Konya by the thousands on the anniversary of his death (shab-i carüs), and remember him with ceremonies. Contrary to common perceptions, al-Rūmī assumed the responsibility of the city in a historical sense, and this affinity with him gave the city "an honor," "a privilege," and "a source of pride." Therefore, for an ordinary city resident, Konya is a holy city, which undoubtedly led to this common belief: a city that is blessed will have a deep impact on its daily life. In a blessed city, the things that contravene the "spirituality of the city" are shunned because such things lead to social conflicts that are difficult to settle.

While a reference can be made to the established and positive history of a city, mention can also be made of its mythical history. The meeting point of these two elements has turned Konya into a highly mystical and pious city. Sociologically, the city bases itself on such myths. Therefore, pursuing daily life practices in the case of Konya is of great significance. Al-Rūmī's discourse and a rich spirituality incorporated in life after being created in such a tradition gradually became the basic norms that form Konya's actual reality. In short, the overall image created by a combination of these components has given Konya a spiritual and mystical image.

12 See Tuncer Baykara, Türkiye Selçuklular Devrinde Konya [Konya in the Period of the Seljuqs of Turkey] (Ankara: Kültür ve Turizm Bakanlığ1 Yayınları, 1985).

13 This is so much so that Konya was always in the position of a city over which bargains were made in the conflicts and strife between the Karamanoghlus and the Seljuqs. However, the problems caused by this appeal of Konya are quite a few. For example, during Tamerlane's famous campaign in Anatolia and the Jalālì uprisings, Konya was in serious trouble. 


\section{New Components: "Today, new things must be said"}

Since the early times through the present, the traditions that are constantly reproduced in daily life, and above all its past, enable Konya to be described as a respectable and magnificent city and make it necessary to pay attention to it. Konya has always been renowned as a historically prestigious city from the Romans to the Byzantines, the Seljuqs to the Ottomans, and finally to present-day Turkey. Today, Konya attracts attention with a constantly renewed image of its everyday life. However, it is important to question what type of relationship Konya will establish with the global demands in a world consisting of new lifestyles and equipped with new technologies. In this world, new relationships of dependence will likely emerge, and the resultant cultural contrasts will bear social risks. ${ }^{14}$

When the Republic was founded, Konya had aesthetic qualities that could be considered typical of Seljuq in terms of heritage. Several Ottoman elements were also complementary to these qualities. This aspect of Konya, which has always allowed it to be defined in terms of the traditional and the religious, must be viewed from these fundamental characteristics. As a Seljuq-Ottoman city, Konya implemented its urban development through a combination of family, neighborhood, and religious communities, similar to other traditional cities: the family as the smallest unit, then the neighborhoodprotective, as well as encompassing and formations of religious communities that extend beyond local boundaries. ${ }^{15}$ The religious

14 In his descriptions of Turkey's leading cities in his book Five Cities published in the mid-20 $0^{\text {th }}$ century, famous Turkish novelist Ahmet Hamdi Tanpinar (19011972) aptly describes the frustration created by rapid and radical change in the cities, among which Konya was included (2004). What Tanpinar mentions is "the regret felt for those that disappeared from our lives and the enthusiasm felt for the new." Even so, the dilemma felt by Tanpinar gives way to balance and peace as far as Konya is concerned. Konya clearly retains its exceptional status in this conflict. According to him, Konya possesses a unique correlation of nostalgic feelings towards the past, reality of today, and expectations from the future.

15 See Musa Çadırc1, Tanzimat Döneminde Anadolu Kentlerinin Sosyal ve Ekonomik Yapları [Social and Economical Structures of Anatolian Towns in Tanzìmāt Reform Era] (Ankara: Türk Tarih Kurumu, 1991); Özer Ergenç, Osmanl Klasik Dönemi Kent Tarihçiliğine Katkl: XVI. Yüzylda Ankara ve Konya [Contribution to Urban Historiography of Classical Ottoman Period: Konya in XVIt Century] (Ankara: Ankara Enstitüsü Vakf1, 1995); Suraiya Faroqhi, Osmanl Kültürü ve Gündelik Yaşam: Ortaçağdan Yirminci Yüzynla [Kunst und alltagsleben im 
community, or $j a m \bar{a}^{c} a$, was part of the social imagination created by the world of daily relationships. An ordinary individual in an Anatolian city internalized the Ottoman identity by roaming through a web of bonds generated by the neighborhood and the religious community. Communal bonds developed around masjids, or small mosques, which existed in almost all streets, and mosques and lodges of religious sects that were bigger than masjids, which justified the existing variety through larger numbers of participants. The teachings of the 'ulam $\bar{a}$ ', the scholars of Muslim theology, were influential in the practical demonstration of religiosity. However, religious communities and groups were equally as important as the 'ulam $\bar{a}^{\text {' }}$ - they were structures that tolerated areas of tension between the state and the society. Especially when urban life is considered, the answer to the question of how the gap between the state and the society will be filled, and what social institutions will undertake this responsibility when Muslim communities are concerned, is through religious sects. As emphasized by Işın, ${ }^{16}$ this role must be understood properly:

The question of cultural roaming among groups of different status brought along with social stratification draws attention to another manner of activity assumed by sects in urban life. This manner of activity addresses the feeling of belonging to a religious community existing in the collective subconscious of urban residents and help people of different status meet in a common ground by way of mystic metaphors it uses. We may regard the ground where such a union of understanding and feeling materializes as the strongest social structure which enables cultural circulation among the groups in question. The classic assumption that each sect generates the culture of a group of a different status has no validity at all. In fact, we must state here that this joint union of understanding and feeling, termed nash' $a$, or joy, in the mystical language both substitutes for the dynamics of cultural circulation among status groups and at the same time allows for a form of individual perception best fitting for human nature. The sects' keeping open such a channel of cultural circulation, both ends of which open to the humans and the society, played the primary role in the emergence of urban life. Moreover, this role has a historical di-

Osmanischen Reich] (translated into Turkish by Elif Kılıç; Istanbul: Tarih Vakfı Yurt Yayınlar1, 1997).

16 See Ekrem Işın, İstanbul'da Gündelik Hayat: Insan Kültür ve Mekân İlişkileri Üzerine Toplumsal Tarih Denemeleri [Daily Life in Istanbul: Social History Essays on Human, Culture and Space Relations] (Istanbul: İletişim Yayınları, 1995). 
mension: thanks to such a channel of communication that was granted functionality by the sects on a common cultural ground, knowledge, and experience are passed on from one generation to another and thus the collective memory of the society is established.

It must not be forgotten that in Konya, the 'ulama' ' from madrasas (religious schools) and members of religious groups who managed to establish more insightful and lasting relationships with people of all professions and walks of life had an effective role that transformed the natural-secular nature of daily life ${ }^{17}$ - so much so that the historical cost of these roles of the 'ulama' ' and the groups almost justifies most of the ideological references that have codified Konya as "the source of religious backwardness/bigotry" since the establishment of Republic.

Turkish modernization upset the established daily life patterns. When tradition is defined, a larger framework that also includes religion is emphasized. Turkish politicians who were nurtured by the founding values of modernization dared to engage in an open conflict with the traditional. Although the speed of the revolutionary orientation of Turkish modernization has considerably slowed today, its effect has gained increasing continuity. The leaders of the new regime, from the very beginning, agreed on disdaining, excluding and when deemed necessary, suppressing religion as a reference value. In this chaotic atmosphere, only a world of reference approved by the state could exist. It was out of the question that Konya could have privileged treatment in its inclusion in modern Turkey's direction. However, even a simple comparison of what type of appearance modernization allowed could suffice to expose the difference in various regions of Turkey. Indeed, even Konya's neighbors could not synchronize with Konya in maintaining the delicate balance between modernity and adherence to tradition. As Aktay noted, Konya is unique in this regard because although it has always maintained a lukewarm attitude towards basic tenets of Turkish modernism, Konya has employed a policy of real-politics concerning the nature of modernism - so much so that Konya's experience of modernization does not conflict ideologically with the discourse of the Kemalist elite; nevertheless, universal knowledge and the reality of everyday

17 Cf. Caner Arabac1, Osmanl Dönemi Konya Medreseleri 1900-1924 [Konya Madrasas in the Ottoman Period: 1900-1924] (Konya: Konya Ticaret Odas1, 1998). 
life contribute significantly to the development of this imagination and determination of its direction. ${ }^{18}$

In the case of Konya, what lies within the content of this contribution is a combination of religion, tradition, and modernity. Both religion and tradition are still the major creators of the mental world of a typical Konya native. The existence and weight of a tradition of common sense and respectable ' $u l a m \bar{a}$ ' that did not allow bigotry or heretic sects are factors that should not be disregarded. The weight of ' ulam $\bar{a}$ ' was always visible in the rational characteristic of religious orientations. This emerging weight regarded marginal movements and changes of axis as negative indicators, and such organizational efforts were taken as malformations. Although this weight of ' ulama $\bar{a}$ ' was substantially eroded during the Republican Era, its respectability still holds.

Throughout the Republican Era, as security and controlling devices of the state, İmam-Hatip (Imam and Preacher) Schools, ${ }^{19}$ and also imāms affiliated to Directorate of Religious Affairs, who are in charge of conveying the official understanding of religion to the society,

18 See Celalettin Çelik, Şehirleşme ve Din [Urbanization and Religion] (Konya: Çizgi Kitabevi Yayınları, 2002); Sencer Ayata, "Çevresel Nitelikteki Geleneksel Tarikatlar: Konya ve Trabzon'da Kadiri ve Nakşibendî İslâm [Islamic Literature and Literacy in Contemporary Turkey: Traditional Sufi Orders on the Periphery: Kadiri and Nakşibendi Islam in Konya and Trabzon]" in Richard Tapper (ed.), Çağdaş Türkiye'de İslâm: Din, Siyaset, Edebiyat ve Laik Devlet [Islam in Modern Turkey: Religion, Politics and Literature in a Secular State] (translated into Turkish by Özden Arıkan; Istanbul: Sarmal Yayınevi, 1993), 133-170; Ali Bayramoğlu, Demokratikleşme Sürecinde Dindar ve Laikler [Religious and Lay Persons in Democratization Process] (Istanbul: Türkiye Ekonomik ve Sosyal Etüdler Vakf1, 2006); VERITTR, Avrupa Şehir Şartı ve Konya Araştırması [Europe City Condition and Konya Research] (Konya: Konya Ticaret Odas1, 2005); SİAR, Dinî Değerler Arasstırması [Religious Values Research] (Istanbul: SİAR, 1985).

19 Initially, İmam-Hatip (Imām and Preacher) Schools were established to graduate enlightened religious men. It is possible to categorize these schools as a unique formation in which two different lines of knowledge, namely "worldly" and "otherworldly," meet in a modern framework. Nonetheless, the Kemalist elite often have misgivings about the knowledge and the human element generated in Imam-Hatip Schools. The rapid increase in their number and their appeal to the public soon made Imam-Hatip schools one of the issues of tension between laicism and religion. Now, İmam-Hatip Schools have been codified by the modernist Kemalist elite as the breeding ground for Islamic movements. Ultimately, many restrictions was imposed on graduates of these schools until very recently. 
have displayed an attitude that extinguished tensions and conflicts in the face of every instance of manipulation from the superiors regarding the regulation of daily life. Sermons, lectures, and assemblies of enlightenment, and even religious ceremonies have contributed to the justification of such attitudes. Thus, a certain continuity has been achieved in Konya that has separated spirituality from verbal and formal essentialism in a more radical manner than what has transpired in many other regions of Turkey. The major principle that İmam-Hatip Schools, Higher Institutes of Islam, ${ }^{20}$ Faculties of Theology after the 1980s and the personnel at Directorate of Religious Affairs have crystallized for daily life is "to progress;" however, the original goal is not to get away from the main paradigm while implementing this goal. The notion of progress here was different from the notion of progressivism in the Western discourse of Enlightenment. What happened was associating words with Western words in appearance but filling their content with Islamic terminology. The images and the ideas that emerged and proliferated in a new form were entirely modern. Even if they were entangled in the nets of the past, unconditional rejection of the modern did not receive mass approval. In actuality, this situation was a testament to Konya's uniqueness. Within this combination, Konya has begun to generate concrete examples of its own specific modernization with its characteristics that it has displayed with more emphasis, especially since the 1990s. It is possible to detect a re-reading of the tradition behind all of these. It would be fitting to cite here the sayings of Prophet Muhammad and Mawlānā Jalāl al-Dīn which translate as follows respectively: "The one who spent two days with equal performance does not belong to us" and "yesterday went along with yesterday; it is necessary to say new things today."

Urban life involves a constant search for harmony. The necessity for co-habitation renders efforts in this regard to be highly valuable. In this framework, different criteria are reproduced. Agreeing with the shared principles of the city may create the danger of eliminating

20 Initially, these institutes and faculties were opened to graduate teachers of religion for various secondary education schools, especially İmam-Hatip Schools, or to educate personnel for the religious bureaucracy to be employed as muftis and preachers in the central and provincial branches of Presidency of Religious Affairs. The controversy about the justification and functions of these schools has assumed a permanent status as consequence of the fact that the secular orientations of the state do not have a truly genuine route. 
new approaches on an individual or social level. The fear of getting lost in the same pot and course encourages the emergence of ghettos. In contrast, Weber proposes just the opposite: ${ }^{21}$ "The city removes all ties." This "removal of ties" allows for new formations and organizations that will introduce an urban lifestyle. The values, traditions and value judgments are subjected to a new test. However, what continues to exist in Konya is an expression of a different co-existence.

\section{Aşure ( $(\bar{A} \boldsymbol{s} h \bar{u} r \bar{a})$ ) as a Metaphor for a Model of Cultural Plu- rality}

The real source of controversy surrounding Konya is whether the newcomers mix with the natives. Every lifestyle proposal that comes from outside will either succeed or adapt to the social atmosphere of the society they join, become creolized through transformation, and will perhaps maintain its specific identity. In fact, however, those who come to Konya add their own characteristics to the city and do not express themselves with a different identity. The fact that those who come from outside are also Muslims facilitates integration. Without explicit suggestion, "The Dome" in Konya attracts and incorporates the stranger to a specific culture, and ultimately makes him either religious or secular. However, individual dissensions cannot evade Konya's encompassing power. How is it possible that the modus operandi that operates in Konya fosters piety? It cannot be denied that the effects of modernization and westernization that we experience in our lives are felt here as occurs everywhere else in Turkey. The practice of building daily life on secular values functions in Konya just as anywhere else. Nevertheless, mention has to be made of a "specific style" in Konya, because the unity that forms here does not eliminate cultural, religious, and ethnic differences. In fact, it is possible to discuss a common ground among all of these structures.

This common ground in Konya can only be expressed through the metaphor of aşure. Aşure is a dessert that is made from a variety of ingredients. There is a common belief about the origin of assure, which is made by boiling wheat, chickpeas, and other grains with dried fruit. The day of ' $\bar{a} s h \bar{u} r \bar{a}$ ') is on the tenth of Muharram, which is the first of the lunar months in the Islamic calendar. Historical and religious stories note that important events took place on this day in the lives of many prophets. On this day, many prophets were saved

21 See Max Weber, Şehir: Modern Kentin Doğuşu [The City] (translated into Turkish by Musa Ceylan; Istanbul: Bakış Yayınları, 2000). 
from various big problems, oppressions, and persecutions. According to these stories, certain incidents occurred on the day of ' $\bar{a} s h \bar{u} r \bar{a})^{22}$ The most frequently made connection with asure in the Islamic world is the murder of Prophet Muhammad's grandson, al-Husayn, at alKarbalā'. Today, aşure has an important ritualistic value as a constantly updated story among all Muslims, in particular the Shī'ite and the Alevi. ${ }^{23}$

Each ingredient used in asure manages to retain its specific taste. Furthermore, all these ingredients create a completely new taste. This is more functional for Konya than that of the "salad bowl" given for the American and Canadian cases because of both the cultural uniqueness of the concept of asure and the unrealistic suggestion that the ingredients that come together in a salad do not undergo transformation. We know that no cultural encounter can be possible without a certain amount of interaction. In the case of assure, although all the ingredients mix and mingle with one another in the same pot, the ingredients do not change their characteristics in the end. As is emphasized by Boysan, aşure is a mixture of elements that generate a new taste when they come together despite their dissimilarity. For example, ${ }^{24}$

The truth behind how the chickpea and the dry fig come together cannot be grasped. All the same, just like aşure, there are blends of humans from whose gathering a sweet atmosphere arises and there are cities as their location. (...) However, what gives taste to assure and heats it is the fire. The name of the fire that enables mixing well in human gatherings is culture. The destiny of human communities not heated by the fire of culture is to remain permanently at the stage of salad.

Thus, a new taste emerges as a combination of each taste felt indi-

22 Among them are God's acceptance of the repentance Prophet Adam for the sin he committed, the salvation of Noah's ark from the great flood, Prophet Abraham's not getting burned in the fire, the ascension of Prophet Driss to the heavens, Prophet Jacob's meeting his son Prophet Joseph, Prophet Job's recovery from his illness, Prophet Moses' crossing the Red Sea and saving the Jews from the persecution of the Pharaoh and lastly Christ's birth, his salvation from death and ascension to the heavens.

23 See Metin And, Ritüelden Drama: Kerbelâ-Mubarrem-Ta'ziye [From Ritual to Drama: al-Karbalā'-Muharram-Ta'ziya] (Istanbul: Yap1 Kredi Yayınlar1, 2002).

24 See Aydın Boysan, Nerede Yassıyoruz? [Where Do We Live?] (Istanbul: Bilgi Yayınevi, 2004). 
vidually. Konya must be regarded in the context of this specific combination. ${ }^{25}$

The sociological literature did not delay in analyzing mental structures and orientations activated by the urban context. In fact, the most profound problems of modern life arise from the individual's desire to retain his/her existential autonomy and individuality in the face of effective social forces, historical legacy, external culture, and lifestyle ${ }^{26}$.

In this framework, urbanization epitomizes the formation of the "people" in a new formula, and that which is daily reflects meeting points where this variety emerges in search of harmony away from sharp boundaries. According to a common assumption regarding the nature of sociological relationships, while urbanization generates its own tradition, daily life takes form as a harvest ground where materials and accessories in the cultural-intellectual depot are re-processed. Lifestyles and life patterns always emerge by differentiating from urban experiences, but still it is not always possible to talk about the uniqueness of urban practices. The process of urbanization can also be defined as a new aspect of life that introduces changes of social structure such as division of workload and specialization. Ultimately, this process paves the way for secularism, individualization, establishing anonymous and rational relationships. Thus, life's values, manners, and attitudes begin to be adopted. Tradition is not appreciated and therefore comes into contact with new forms.

In this context, Konya displays a distinct characteristic that sometimes confuses sociological theory. However, the interest in what is

25 Here there is something different from the one achieved with the "melting pot." What is expected of each element in the melting pot is creolization. Here, the goal is to create new social and cultural forms or identities out of those who belong to different cultural, religious, and ethnic groups. This "melting pot" is now an amalgam. As transpired from many practices ranging from assimilation to integration, the elimination of the original root in a "melting pot" has been considered among the requirements of the social order (Cf. Nazım İem "Eritme Potasından Eriyen Pota’ya: XXI. Yüzyılın Eşiğinde Amerika [From Melting Pot to Melted Pot: America on the Verge of XXI ${ }^{\text {th }}$ Century]," Doğu-Batı 8/32 (MayısTemmuz [May-July] 2005), 199-219). However, the essence of aşure is to preserve differences with their root qualities and ensure constant maintenance of a balance.

26 Georg Simmel, "Metropol ve Zihinsel Yaşam [The Metropolis and Mental Life]," Cogito 8 (1996), 81-89. 
modern is selective. Here, it is difficult to define the traditional characteristic of the city as a monotonous embodiment of the past; it is actually the continuous mobilization of the materials at hand in building bridges between the past, present, and the future. In this framework, the appeal of religion, mysticism and modernity constitutes the fundamental elements of daily life - so much so that even new urbanization strategies usually tend to transform old structural characteristics rather than remove them. Business centers, new neighborhoods, increasing centers of concentration, and diverging orientations in urban atmosphere turn Konya into a mold where differentiations are tolerated.

Undoubtedly, one of the factors that foster this perception is the fact that what is religious has taken a genuine form. When patterns of social life are considered, mosques reflect identity to a large extent and are popular with the $j a m \bar{a}^{c} a$, or the congregation. Nonetheless, some ancient historical sites that may be cited among the primary indicators of Seljuq and Ottoman existence in the city receive their share of the tensions that arise from daily life practices. ${ }^{27}$

27 An ultra-modern shopping center where representatives of all capitalist brands exist was built by the so-called religious capital in the center of Konya. The prominent architectural feature of this center is its revolutionary height and style for Konya. Apart from the traditional Islamists who usually disapprove of high-rising construction (since tall buildings are usually regarded as ominous signs of the Doomsday), this building also received much criticism from the conservatives. Controversy is still going on about the representative quality for Konya of the construction of a new business center with its unusual height even for the whole of Anatolia (42-storey to match Konya's traffic plate number). Konya's public opinion has not yet agreed on the name to be given to this skyscraper. Should the skyscraper be referred to with a western name like Kule City (Tower City) or one like Selçuklu Kulesi (Seljuq Tower) which revives historical memories? Now, the building began to be called kule site by the public in daily life thanks to a certain understanding of reconciliation. However, the conservative democrat municipal administration insists on calling this structure Selçuklu Kulesi (Seljuq Tower). The important thing here is not the placement of a rather assertive and imposing building in the center of the city in contrast to the religious objection to the construction of high buildings. The fact that this building is generating a new style of behavior and everyday life culture by bringing along a new type of consumer prototype is a much more important aspect of this building in contrast to the luxury shops in various parts of the city. The interesting thing, however, is the enthusiasm to name a highly modern building with the Seljuq heritage. The building bears no elements of traditional architecture, yet the phrase Seljuq is enough 
It is appropriate to say that daily life in Konya is now reproduced by blending the traditional and the modern. As was revealed by research conducted in recent years, Konya displays a cautious attitude towards both zealous Islamic radicalism and equally zealous modernization movements. ${ }^{28}$ Although Konya is often cited as a favorable ground for harboring fundamentalist interpretations of Islam, the number of examples that disprove such expectations both in theory and practice are quite a few. Despite the fact that Konya has preferred political tendencies with high Islamic emphasis since the 1970s, it has always demonstrated a measured and discreet attitude to avoid turning this tendency into an urban conflict. ${ }^{29}$ In this framework, Konya has set up its inner balance and limited the aspirations of extremists. Despite the visible weight of religious and conservative tendencies, Konya has given support to all of the political parties that have emerged in political arena. ${ }^{30}$ However, Konya comes to the fore-

to activate a search for defined roots. The semantic world created around kule site (Tower Site) goes beyond outward modernization and verbal traditionalism and provokes important questions in the context of Konya about how a new life style can be created.

28 See Birol Akgün, Türkiye'de Seçmen Davranışı, Partiler Sistemi ve Siyasal Güven [Voter Behaviors, Political Parties System and Political Confidence in Turkey] (Ankara: Nobel Yayın Dağıtım, 2002); Muammer Gül, Atilla Bayram, and Oğuzhan Hakkoymaz, Selçuklu'dan Günümüze Konya'nın Sosyo-Politik Yapısı [Sociopolitical Structure of Konya from the Seljuq Era to the Present] (Konya: Il Emniyet Müdürlüğ̈̈ AR-GE Yayınlar1, 2003); GENAR, Konya Büyükssehir Belediyesi Sosyal Kriterler Iletişim Konsepti ve Uygulama Projesi [The Communication Concept of Social Criteria and Its Application Project, Konya Metropolitan Municipality] (Konya: Büyükşehir Belediyesi, 2004); Konya Ticaret Odası (KTO) [Konya Chamber of Commerce], Konya İli Sosyo-Ekonomik ve Siyasi Yönelimler Araştırmast-2 [A Research on Socio-economic and Political Orientation of Konya-2 ] (Konya: Konya Ticaret Odas1, 2005); SİAR, ibid.

29 The place which Necmeddin Erbakan, who represents the religious wing in Turkish politics, chose for his project and discourse (Milli Görüş, or The National View) has always been Konya. Nevertheless, this affinity between the city and Erbakan did not prevent the emergence of social democrat or democratic formations in their own way. There is no favorable atmosphere in Konya now to represent Erbakan's discourse in the political arena. In contrast, conservative democrat Tayyip Erdoğan has managed to be influential in Turkish politics with a grassroots political platform that also includes remnants of the Milli Görüş Movement.

30 See KTO, ibid:; Muhiddin Tuss, Sosyal ve Ekonomik Açıdan Konya [Konya with regard to Socio-Economic Aspects] (Konya: Konya Ticaret Odas1, 2001). 
ground as a city where religious tendencies are associated with political demands in daily life.

The remembrance of Konya with a perception of modernity is linked to the economic boom there. ${ }^{31}$ The developmental statistics which used to seem to justify the popular perception that Konya is ignored by the administrators of the modern Republic have begun to change rapidly in recent years. ${ }^{32}$ Industrial businesses that concentrate in Konya, economic revival, and the development of similar factors that do not exclude traditional and religious points of reference indicate the continuity and prevalence of a remarkable living pattern in Konya. In fact, the industrial sector in Konya leads the entrepreneurs that are called Anatolian Tigers ${ }^{33}$ and are expanding rapidly. The holding companies that are established there and developments in the industrial sector operate independently of the religious and traditional reference points.

Thus, urban life is becoming increasingly modern. Modern life can only be based on a system. However, what is unusual is an Islamic modernization and, as has been frequently stated, this brings to mind a totally peculiar concept of modernization. What happens here is the inclusion of both modernity and the reproduced religious and traditional past in daily life rather than the conquest of the center by modernity.

In conclusion, Konya bears the quality of being an interesting city in that it has confronted and gradually reconciled the rules of modern life with its religious orientations which have constantly been given fresh impetus since al-Rūmī, and which have given priority to expertise and genuine knowledge over heretic views. The question to which Yahya Kemal sought an answer requires the implementation of

31 See Bülent Dinçer, Metin Özaslan, and Taner Kavasoğlu, Illerin ve Bölgelerin Sosyo-Ekonomik Gelişmişlik Stralaması Araştırması [A Research on the SocioEconomic Development Order of Cities and Regions] (Ankara: Devlet Planlama Teşkilat1, 2003).

32 See Devlet İstatistik Enstitüsü (DİE) [State Institute of Statistics], Ekonomik ve Sosyal Göstergeler - Konya - [Economic and Social Indicators - Konya -] (Ankara: DİE, 1998); idem, 2000 Genel Nüfus Sayımı: Nüfusun Sosyal ve Ekonomik Nitelikleri - Konya - [General Census 2000: Social and Economic Features of Konya's Population] (Ankara: DİE, 2002).

33 Anatolian Tigers have represented since the 1980's the new entrepreneurialism of the religious and conservative businessmen in Anatolia unlike the mostly Ankara and Istanbul-based and state-favored Turkish businessmen. 
more insightful research regarding how this conflict has been removed in the case of Konya. The question should be this: what kind of a balance do those who manage to wake up to perform the Early Morning Prayer establish between their daily life and modernity?

\section{REFERENCES}

Akgün, Birol, Türkiye'de Seçmen Davranışı, Partiler Sistemi ve Siyasal Güven [Voter Behaviors, Political Parties System and Political Confidence in Turkey] (Ankara: Nobel Yayın Dağıtım, 2002).

And, Metin, Ritüelden Drama: Kerbelâ-Mubarrem-Ta'ziye [From Ritual to Drama: al-Karbala'’-Muharram-Ta'ziya] (Istanbul: Yap1 Kredi Yayınlar1, 2002).

Arabac1, Caner, Osmanl Dönemi Konya Medreseleri 1900-1924 [Konya Madrasas in the Ottoman Period: 1900-1924] (Konya: Konya Ticaret Odas1, 1998).

Ayata, Sencer, "Çevresel Nitelikteki Geleneksel Tarikatlar: Konya ve Trabzon'da Kadiri ve Nakşibendî İslâm [Islamic Literature and Literacy in Contemporary Turkey: Traditional Sufi Orders on the Periphery: Kadiri and Nakşibendi Islam in Konya and Trabzon]" in Richard Tapper (ed.), Çă̆daş Türkiye'de İslâm: Din, Siyaset, Edebiyat ve Laik Devlet [Islam in Modern Turkey: Religion, Politics, and Literature in a Secular State] (translated into Turkish by Özden Arıkan; Istanbul: Sarmal Yayınevi, 1993), 133-170.

Bahar, Hasan \& Karauğuz, Güngör \& Koçak, Özdemir, Eskiçă̆ Konya Araşttrmalar I: Phrygia Paroreus Bölgesi Anttlar, Yerleşmeler ve Küçük Buluntular [Studies on Konya in Ancient Times I: The Region of Phrygia Paroreus Monuments, Settlements, and Small Findings (Istanbul: n.p., 1996).

Bahar, Hasan \& Koçak, Özdemir, Eskiçağ Konya Araştırmalar II: Neolitik Çă̆'dan Roma Dönemi Sonuna Kadar [Studies on Konya in Ancient Times II: From the Neolithic Age to the End of the Roman Period] (Konya: Kömen Yayınları, 2004).

Baykara, Tuncer, Türkiye Selçuklular Devrinde Konya [Konya in the Period of the Seljuqs of Turkey] (Ankara: Kültür ve Turizm Bakanlığg Yayınlar1, 1985).

Bayramoğlu, Ali, Demokratikleşme Sürecinde Dindar ve Laikler [Religious and Lay Person in Democratization Process] (Istanbul: Türkiye Ekonomik ve Sosyal Etüdler Vakf1, 2006). 
Beyatl, Yahya Kemal, Aziz İstanbul [Glorious Istanbul] (Istanbul: İstanbul Fetih Cemiyeti, 1964).

Bilgin, İhsan, "Modernleşmenin Şehirdeki İzleri [Marks of Modernisation in the City]," www.arkitera.com/v1/diyalog/ibsanbilgin/modernizm1. btm (2002).

Boysan, Aydın, Nerede Yaşıyoruz? [Where Do We Live.] (Istanbul: Bilgi Yayınevi, 2004).

Çadırc1, Musa, Tanzimat Döneminde Anadolu Kentlerinin Sosyal ve Ekonomik Yapilar [Social and Economical Structures of Anatolian Towns in Tanżimāt Reform Era] (Ankara: Türk Tarih Kurumu, 1991).

Çelik, Celalettin, Şebirleşme ve Din [Urbanization and Religion] (Konya: Çizgi Kitabevi Yayınları, 2002).

Devlet İstatistik Enstitüsü (DİE) [State Institute of Statistics], Ekonomik ve Sosyal Göstergeler - Konya - [Economic and Social Indicators - Konya -] (Ankara: DİE, 1998).

2000 Genel Nüfus Saymm: Nüfusun Sosyal ve Ekonomik Nitelikleri Konya - [General Census 2000: Social and Economic Features of Konya's Population] (Ankara: DİE, 2002).

Dinçer, Bülent \& Özaslan, Metin \& Kavasoğlu, Taner, Illerin ve Bölgelerin Sosyo-Ekonomik Gelişmişlik Siralaması Araştırması [A Research on the Socio-Economic Development Order of Cities and Regions] (Ankara: Devlet Planlama Teşkilatı, 2003).

Ergenç, Özer, Osmanl Klasik Dönemi Kent Taribçiliğine Katkı: XVI. Yüzyulda Ankara ve Konya [Contribution to Urban Historiography of Classical Ottoman Period: Konya in XVI ${ }^{\text {th }}$ Century] (Ankara: Ankara Enstitüsü Vakf1, 1995).

Faroqhi, Suraiya, Osmanl Kültürü ve Gündelik Yaşam: Ortaçağdan Yirminci Yüzyla [Kunst und alltagsleben im Osmanischen Reich] (translated into Turkish by Elif Kılıç; Istanbul: Tarih Vakfı Yurt Yayınlar1, 1997).

GENAR, Konya Büyükşehir Belediyesi Sosyal Kriterler Iletişim Konsepti ve Uygulama Projesi [The Communication Concept of Social Criteria and Its Application Project, Konya Metropolitan Municipality] (Konya: Büyükşehir Belediyesi, 2004).

Gül, Muammer \& Bayram, Atilla \& Hakkoymaz, Oğuzhan, Selçuklu'dan Günümüze Konya'nın Sosyo-Politik Yapısı [Sociopolitical Structure of Konya from the Seljuq Age to the Present (Konya: İl Emniyet Müdürlüğü AR-GE Yayınları, 2003). 
Işın, Ekrem, Istanbul'da Gündelik Hayat: Insan Kültür ve Mekân İlişkileri Üzerine Toplumsal Tarih Denemeleri [Daily Life in Istanbul: Social History Essays on Human, Culture and Space Relations] (Istanbul: İletişim Yayınları, 1995).

İrem, Nazım, "Eritme Potasından Eriyen Pota’ya: XXI. Yüzyılın Eşiğinde Amerika [From Melting Pot to Melted Pot: America on the Verge of XXI $^{\text {th }}$ Century]," Doğu-Batı 8/32 (Mayıs-Temmuz [May-July] 2005), 199-219.

Jusdanis, Gregory, Gecikmis Modernlik ve Estetik Kültür [Belated Modernity and Aesthetic Culture] (translated into Turkish by Tuncay Birkan; Istanbul: Metis Yayınları, 1998).

Kara, İsmail, "İslâm Düşüncesinde Paradigma Değişimi: Hem Batılılaşalım Hem de Müslüman Kalalım [Paradigm Shift in Islamic Thought: Let's Both Become Westernalized and Remain Muslims]" in Mehmet Ö. Alkan (ed.), Modern Türkiye'de Siyasi Düşünce: Tanzimat ve Messrutiyet'in Birikimi [Political Thought in Modern Turkey: Accumulation of Tanzimāt and Constitutionalism] (Istanbul: İletişim Yayınlar1, 2001), I, 234-264.

Konya Ticaret Odası (KTO) [Konya Chamber of Commerce], Konya İli SosyoEkonomik ve Siyasi Yönelimler Arassttrmast-2 [A Research on Socioeconomic and Political Orientation of Konya-2] (Konya: Konya Ticaret Odas1, 2005).

Konyalı, İbrahim Hakk1, Abideleri ve Kitabeleriyle Konya Taribi [History of Konya with Memorials and Epitaphs] (Konya: Yeni Kitap Basımevi, 1964).

Lefebvre, Henri, Modern Dünyada Gündelik Hayat [La Vie Quotidienne Dans le Monde Moderne] (translated into Turkish by Işın Gürbüz; Istanbul: Metis Yayınları, 1998).

ÖzÖnder, Hasan, Konya Velileri [Saints of Konya] (Konya: Kuzucular Ofset, 1990).

Reed, Howard Alexander, "Çağdaş Türk Müslümanlarının Dinî Hayatı [Religious Life of Modern Turkish Muslims]" in Davut Dursun (ed.), Türkiye'de İslâm ve Laiklik [Islam and Laicism in Turkey] (Istanbul: İnsan Yayınlar1, 1995).

SİAR, Dinî Değerler Araştırması [Religious Values Research] (Istanbul: SİAR, 1985).

Simmel, Georg, "Metropol ve Zihinsel Yaşam [The Metropolis and Mental Life]," Cogito 8 (1996), 81-89. 
Subaş1, Necdet, Gündelik Hayat ve Dinsellik [Daily Life and Religiosity] (Istanbul: İz Yayınc1lık, 2004).

Tuş, Muhiddin, Sosyal ve Ekonomik Açıdan Konya [Konya with regard to Socio-Economic Aspects] (Konya: Konya Ticaret Odas1, 2001).

Uz, Mehmet Ali, Konya Alimleri ve Evliyalar [Scholars and Saints of Konya] (Konya: Karabulut, 1993).

VERITR, Avrupa Şehir Şartı ve Konya Arasstırması [Europe City Condition and Konya Research] (Konya: Konya Ticaret Odas1, 2005).

Weber, Max, Şebir: Modern Kentin Doğuşu [The City] (translated into Turkish by Musa Ceylan; Istanbul: Bakış Yayınları, 2000). 